\title{
Spatial distribution and environmental correlates of Australian snubfin and Indo-Pacific humpback dolphins
}

\author{
Guido J. Parra, Robert Schick and Peter J. Corkeron
}

\begin{abstract}
Parra, G. J., Schick, R. and Corkeron, P. J. 2006. Spatial distribution and environmental correlates of Autralian snubfin and Indo-Pacific humpback dolphins. - Ecography 29: 000-000.
\end{abstract}

\begin{abstract}
We present data on the spatial distribution of Australian snubfin and humpback dolphins using boat-based line transect surveys in three adjacent bays located in the Far Northern Section of the Great Barrier Reef Marine Park, northeast Queensland. We used Geographic Information Systems (GIS), and both randomization and Mantel tests to examine the relationship between the spatial distribution of the dolphins and three simple, readily quantified, environmental variables: distance to land, distance to river mouth, and water depth. Mantel tests allowed us to make clear inferences about the correlation of the species' distributions with environmental variables, while taking into account spatial autocorrelation and intercorrelation among variables. Randomization tests indicated snubfin and humpback dolphins occur closer to land than would be expected at random. Two-sample randomization tests indicated snubfin dolphins were found closer to river mouths than were humpback dolphins. Taking spatial autocorrelation into account, Mantel tests indicated all environmental variables were correlated with the spatial distribution of snubfin and humpback dolphins. Interspecific differences in spatial distribution appeared to be related to proximity to river mouths. Preference by snubfin and humpback dolphins for nearshore, estuarine waters is likely related to the productivity of these tropical coastal areas. This spatial analysis suggests that existing protected areas in this region may not include the most critical habitats for snubfin and humpback dolphins. The techniques used here shown relationships between the spatial distribution of the dolphins and environmental features that should facilitate their management and conservation.
\end{abstract}

G. J. Parra (guido.parravergara@jcu.edu.au) and P. J. Corkeron, School of Tropical Environment Studies and Geography, James Cook Univ., Townsville, Queensland, Australia, 4811 (present address of P.J.C.: Bioacoustics Research Program, Cornell Laboratory of Ornithology, 159 Sapsucker Woods Rd, Ithaca, NY 14850, USA). - R. Schick, NOAA Fisheries, Santa Cruz Lab, 110 Shaffer Road, Santa Cruz, CA 95060, USA (present address: Graduate Program in Ecology, Duke Univ., Durham, NC 27708, $U S A)$.

The spatial distribution patterns exhibited by animals result from numerous extrinsic (e.g. environmental, anthropogenic) and intrinsic processes (e.g. population dynamics, intraspecific interactions) (May 1984, Borcard et al. 1992, Legendre 1993). Because all approaches to reserve design and implementation implicitly assume some knowledge of the spatial distribution of organisms
(Pressey and Cowling 2001), increased understanding of the spatial distribution of the species of interest should translate to opportunities for managing human activities in order to facilitate their conservation (Hooker et al. 1999, Hortal et al. 2004).

The extent to which fisheries affect coastal ecosystems is of increasing concern (Jackson et al. 2001, Pauly et al.

Accepted 16 November 2005 
2002, Ormerod 2003). Coastal delphinids and phocoenids often are directly affected by fisheries (Caswell et al. 1998, Pichler and Baker 2000, Chilvers and Corkeron 2001). Attempts to regulate the impacts of fisheries on small cetaceans generally include some spatial component (Bräger et al. 2002). Along much of the world's coastlines, however, our knowledge of the distribution and status of delphinids remains poor (Van Parijs et al. 2002). Even though spatial approaches have been used to regulate fisheries impacts on some marine mammals (e.g. Hooker et al. 1999, Marsh 2000) techniques incorporating quantitative estimates of the manner in which dolphins use space into decisions regulating fisheries activity are in their infancy (Bräger et al. 2003).

Australian snubfin dolphins Orcaella heinsohni (Beasley et al. 2005), formerly known as Irrawaddy dolphins $O$. brevirostris, are endemic to the Australian/Papua New Guinean region (Beasley et al. 2005). Indo-Pacific humpback dolphins Sousa chinensis (hereafter simply "humpback dolphins"), are found throughout tropical and subtropical waters of the Indian and western Pacific Oceans (Jefferson and Karczmarski 2001). Relatively little is known regarding the ecology and population status of both species throughout most of their range. The exception to this is off the coast of South Africa (Karczmarski et al. 1999, 2000, Keith et al. 2002) and in Hong Kong waters (Jefferson 2000) where humpback dolphins have been relatively well studied.

In Australian waters, snubfin and humpback dolphins are known to potentially co-occur throughout an extensive part of their range including coastal waters of Western Australia, Northern Territory, and Queensland (Corkeron et al. 1997, Parra et al. 2002, 2004). Very little is known on their ecology and status within Australian waters (Parra et al. 2002, 2004). Both species are listed as Data Deficient under the Australian Cetacean Action Plan (Bannister et al. 1996), and are regarded as species of priority for management and research by the Great Barrier Reef Marine Park (Anon. 2000).

Here, we combined Geographic Information Systems (GIS), and both randomization and Mantel tests to analyse the spatial distribution of Australian snubfin and humpback dolphins in a selected area of northeast Queensland. We used these techniques in order to: 1) determine if the dolphins occurred closer to land, river mouths, and in shallower waters than would be expected by chance, 2) assess these relationships in a way that accounts for spatial autocorrelation in the data, 3) determine interspecific differences in the spatial distribution patterns of snubfin and humpback dolphins, and 4) inform and improve the design of conservation and management actions towards these species.

\section{Methodology}

\section{Fieldwork}

Standard shipboard line transect surveys (Hiby and Hammond 1989) were conducted in October 2001 in 3 adjacent bays located in the Far Northern Section of the Great Barrier Reef Marine Park: Princess Charlotte, Bathurst and Ninian Bays (Fig. 1). Survey time was limited to October because of the remoteness of the study area, the large expenses incurred in conducting the surveys, and the prospects of calm sea conditions during this time of the year (southeasterly trade winds prevail in this region for most of the year). A 20 m, modified trawler with an observer platform $6 \mathrm{~m}$ a.s.l. was used for the surveys. Surveys were conducted in calm sea conditions: Beaufort 3 or less and swells $<1.5 \mathrm{~m}$. All surveys took place between 06:00 and 14:00 $\mathrm{h}$ (wind almost invariably increased in the afternoon, making fieldwork impossible). The survey region was stratified into nearshore $(<10 \mathrm{~km}$ from the coast) and offshore (10$20 \mathrm{~km}$ offshore). Four random lines were run in the offshore area. Transects were perpendicular to the coast and $10 \mathrm{~km}$ long. Within the nearshore survey area transects were spaced ca $3 \mathrm{~km}$ apart, and connected by shorter transect lines ranging between 2 and $4 \mathrm{~km}$ long (Fig. 1). The proximity of nearshore transects to the coast was limited by the $1 \mathrm{~m}$ depth contour (the minimum depth accessible with boat available). Transects in both nearshore and offshore areas were surveyed once.

While the ship was moving at a speed of $10 \mathrm{~km} \mathrm{~h}^{-1}$ along the transect line a team of 3 observers, located on top of the viewer platform (one in the middle and one on each side of boat), searched for dolphin schools ahead and on each side of the boat with the aid of $7 \times 50$ binoculars fitted with a compass and reticle markings. Survey speed was similar to that used with other coastal dolphins and porpoises (e.g. $10-15 \mathrm{~km} \mathrm{~h}^{-1}$ ) that surface inconspicuously (i.e. low surface profile, no splashes, and generally do not leap out of the water, Barlow et al. 1997, Jefferson 2000). A school was defined as dolphins with relatively close spatial cohesion (i.e. each member within $100 \mathrm{~m}$ of any other member) that were involved in similar (often the same) behavioural activities (modified from Connor et al. 1998). While searching, one of the observers maintained a constant search of the area near the boat with unaided eye and binoculars. Once a dolphin school was sighted search effort was stopped to identify species, assess school size, and record behaviour. Sighting distances to dolphin schools were estimated from the compass bearings and reticle readings from the horizon and land (i.e. when land instead of horizon was behind the dolphin school in question) (Buckland et al. 1993, Lerczak and Hobbs 1998). The corresponding distance to land was measured using readings from digital maps on the onboard chartplotter Global Positioning Systems (GPS). Sighting information 
Fig. 1. Map of study area indicating dolphin sighting locations and Great Barrier Reef Marine Park Zoning: transect lines are indicated by solid lines and isobaths by broken lines.

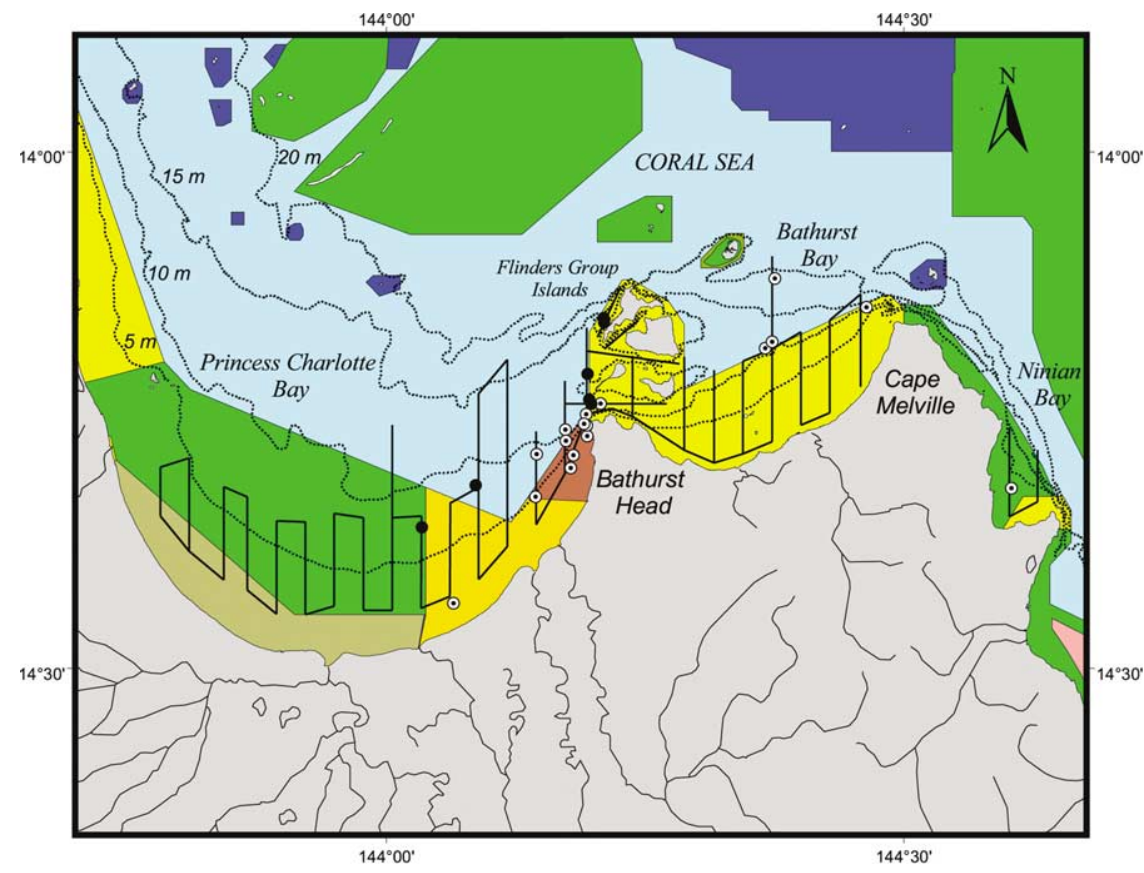

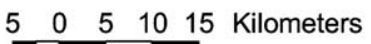
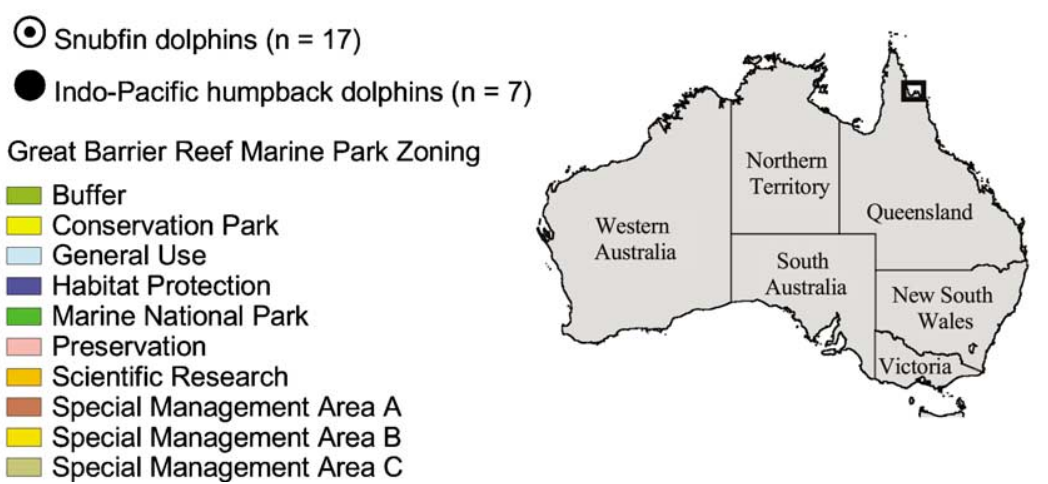

and environmental conditions were recorded and updated as they changed throughout the survey.

\section{Spatial analysis}

ArcView Geographic Information Systems software (GIS) was used to construct a spatial database for each study area integrating dolphin sightings locations in relation to coastline, river mouths, and bathymetry. Geographically referenced digital data for the coastline and estuaries of Queensland (scale 1:100000) were obtained from the Australian National Mapping Agency. Bathymetry data were obtained from the Great Barrier Reef depth model (scale 1:100 000) (Lewis 2001).

From these digital data, three spatial layers were constructed for the following environmental variables: distance to land (i.e. mainland and islands), distance to river mouth, and water depth. The distance to land spatial layer was constructed using a Euclidean distance function (Anon. 1996) to compute the shortest distance to the nearest shoreline. The distance to river mouth was estimated using a cost distance function (Anon. 1996) that computed the shortest distance to the nearest river mouth, taking into account the presence of intervening land (e.g. islands, capes). Additional manual editing of underrepresented water depths in nearshore areas was carried out with the aid of digital georeferenced nautical charts obtained from the Australian Hydrographic Office. To ensure that sampling of environmental variables fell within the area surveyed, a buffer of $1 \mathrm{~km}$, the approximate maximum radial distance at which dolphins were detected, was constructed along the sides of each 
transect. Spatial layers were sampled at a cell resolution of $500 \times 500 \mathrm{~m}$. All spatial layers were projected into Universal Tranverse Mercator (UTM) Zone 55 for distance calculations.

Analysis of spatial data was based on the location of each dolphin school when first seen while on search effort. Dolphin school locations were estimated from boat position, bearings and reticle readings from horizon or land recorded in the field. With selective availability disabled, the position errors of Global Positioning Systems (GPS) are reduced to $\pm 10 \mathrm{~m}$ (Hulbert and French 2001). We also measured the accuracy of our distance to land measurements from the digital maps in the GPS chartplotter navigation system by comparison with measurements from available nautical charts. Corrections were then applied to all estimates of the locations of dolphin schools. Distance formulae which account for the curvature of the earth were used to improve the accuracy of the location estimates of dolphin schools (Lerczak and Hobbs 1998, see also Errata in Mar. Mammal Sci. 144: 903).

\section{Randomization tests}

To determine if the dolphins occurred closer to land, river mouths, and in shallower waters than expected by chance, one-tailed randomization tests were carried out on the observed distribution of each dolphin species (Manly 1997). The randomization test involved comparing the mean values of environmental variables observed at snubfin and humpback dolphin locations with mean values obtained from random locations (equivalent to the number of sightings of each species) within the study area. This procedure was repeated 10000 times, and the significance of the test evaluated by recording the number of times the mean value from random locations was lower than the observed value (Manly 1997).

To assess interspecific differences in the spatial distribution of snubfin and humpback dolphins we conducted a 2-sample randomization test. This randomization compared the difference of the mean distances to land, mean distances to river, and mean water depths at which each species was observed, with the difference obtained by randomly allocating the observed values among the 2 species. POPTOOLS ver. 2.5 was used for resample and randomization tests (Hood 2003).

\section{Mantel tests}

Correlation among species attributes (e.g. distribution, abundance) and environment variables measured at the same sampling locations could reflect a common spatial structure created by biotic (e.g. reproduction, migration) and abiotic (e.g. climate, geology) factors (Legendre and Fortin 1989, Legendre 1993). In the presence of spatial autocorrelation, classical parametric statistics can result in incorrect conclusions regarding species-environment relationships (Leduc et al. 1992, Legendre 1993, Keitt et al. 2002). To assess how much of the observed spatial variation in dolphins distribution was explained by the environmental variables measured, while accounting for spatial autocorrelation in the data, we used simple and partial Mantel tests (Mantel 1967).

The Mantel test is a correlation approach that calculates a statistic analogous to Pearson's $r$ between 2 dissimilarity or distance matrices (Legendre and Fortin 1989, Legendre 1993). A simple Mantel test considers the relationships between predictor (e.g. environmental variables) and dependant variables (e.g. species distribution) as well as their relationship with their location in space, by summarizing space as a geographic distance matrix (Schick and Urban 2000, Urban et al. 2002). A partial Mantel test considers the correlation between environmental variables and species distribution while controlling for spatial autocorrelation and intercorrelation among other variables (Schick and Urban 2000, Urban et al. 2002). The test statistic $r_{M}$ ranges between -1 and +1 , but does not have to be large in absolute value to be significant (Legendre and Fortin 1989). Because the elements of a distance matrix are not independent, a Mantel test of significance is evaluated via permutation by randomly rearranging the rows and columns of the distance matrices. Mantel statistics are recomputed for these permuted matrices, and the distribution of values for the statistic is generated via many iterations (e.g. 10 000) (Manly 1997, Legendre and Legendre 1998).

To explore the overall relationship between the spatial distribution of dolphins and the environmental variables in multivariate terms, we used one-tailed simple and partial Mantel tests between 3 dissimilarity matrices: dolphin occurrence (i.e. presence/absence of dolphins), environment, and space. The dissimilarity matrix of dolphin occurrence was summarized as a binary contrast matrix where sampling sites similar in dolphin occurrence (i.e. both sampling sites have dolphins absent or present), irrespective of species, were coded as 0 and dissimilar sites were coded as 1 (Schick and Urban 2000, Urban et al. 2002). Univariate correlations were also tested by separating the environmental dissimilarity matrix into its constituent variables (distance to land, distance to river mouth, and water depth).

Finally, to test if there was any difference in the spatial distribution patterns between the two dolphin species in relation to the environmental variables, a distance matrix of dolphin species' composition was constructed. Here sampling sites similar in dolphin species' composition (i.e. presence/absence of snubfin and/or humpback dolphins) were coded 0 and dissimilar sites were coded as 1. Multivariate and univariate Mantel tests for the 
correlation of environment variables, dolphin composition, and space were carried out.

Following suggestions on presentation and interpretation of statistical results by Anderson et al. (2001) and Colegrave and Ruxton (2003), observed effect sizes (i.e. difference between means) and Mantel coefficients are reported with their corresponding confidence intervals and p-values. To avoid an uncontrolled inflation of overall Type-I error rates in the multiple randomization and correlation tests; we used the False Discovery Rate (FDR) correction procedure (Benjamini and Hochberg $1995)$ to adjust p-values. We used $95 \%$ confidence intervals together with p-values to evaluate statistical significance of results. Examinations of confidence limits around effect sizes are more informative than p-values in hypothesis testing, as they describe the possible effect sizes that could reasonably be expected in the population based on the empirical data, and assists in the distinction between statistical significance and biological significance (Yoccoz 1991, Thomas 1997). Therefore, if confidence intervals around effect sizes indicated plausible substantial differences or correlations, and $\mathrm{p}$-values were low $(p<0.1)$ we considered the results significant. Confidence intervals of differences between means were obtained by non-parametric bootstrapping using the bias corrected and accelerated method (BCa) (Efron and Tibshirani 1993).

All computations related to simple and partial Mantel tests were carried out using $\mathrm{R}$ software ver. 1.70 (Ihaka and Gentleman 1996) with the aid of a coded R-Library package developed at the Nicholas School of the Environment, Duke Univ. (Goslee and Urban pers. comm; R library available on request from S. Goslee, USDA-ARS PSWMRU, Building 3702, Curtin Road, University Park, PA 16802, USA). Bootstrapping calculations for confidence intervals of differences between means were conducted using the R-package "boot".

\section{Results}

\section{Overall distribution}

We surveyed $431.3 \mathrm{~km}$ (37.8 h of survey effort) within our study area and sighted a total of 17 schools of snubfin dolphins and 7 of humpback dolphins. Snubfin dolphins were sighted in all 3 bays, but most of the sightings occurred around Bathurst Head in Princess Charlotte Bay (Fig. 1). Humpback dolphins were seen in Princess Charlotte Bay only in the vicinity of Bathurst Head, and around the west side of the Flinders Group Islands. Most of the sightings of both species occurred in waters $\leq 5 \mathrm{~km}$ from land, $20 \mathrm{~km}$ from the nearest river mouth, and in waters $<15 \mathrm{~m}$ deep (Fig. 2). a)

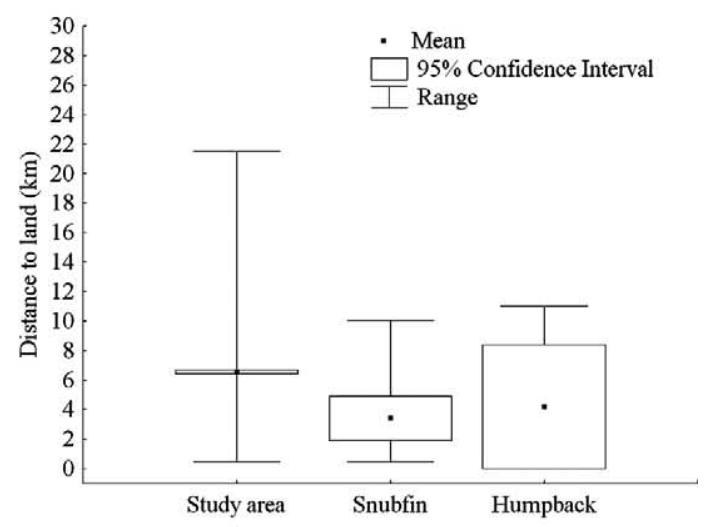

b)

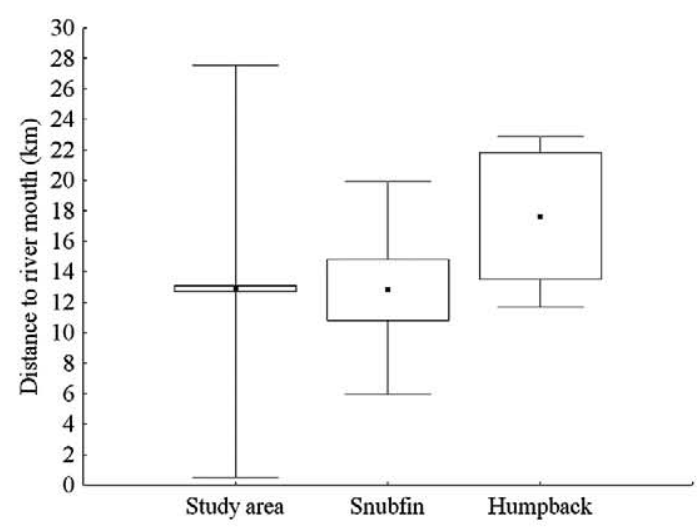

c)

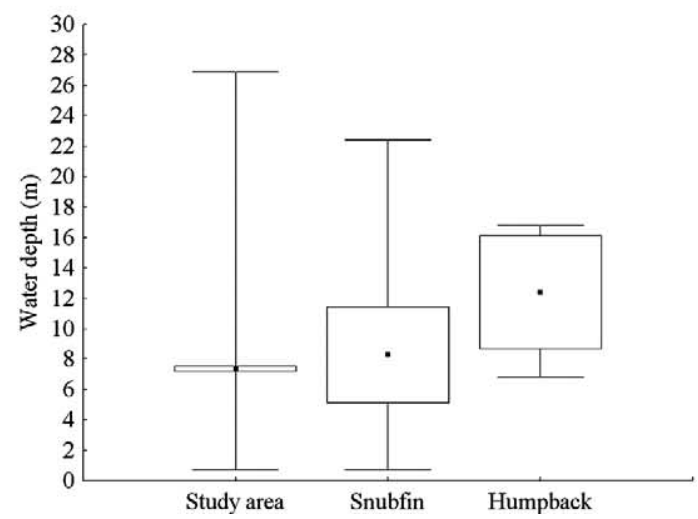

Fig. 2. Mean, $95 \%$ Confidence Intervals, and ranges of distance to land, distance to river mouths and water depth for the study area $(\mathrm{n}=3721)$, snubfin $(\mathrm{n}=17)$, and humpback dolphins $(\mathrm{n}=$ 7). Distances were estimated using the Euclidean distance function within ArcView Geographic Information Systems software (Anon. 1996).

\section{Randomization tests}

Randomization tests indicated that snubfin dolphins occurred closer to land than expected by chance (Table 1, see Fig. 2 for actual distances). The effect size of distance to land for humpback dolphins is not as strong 
Table 1. Effect sizes (95\% confidence intervals in parenthesis) followed by corresponding p-values from randomization tests. First two rows indicate snubfin and humpback dolphins occurred closer to land than would be expected at random in the study area (see Fig. 2 for actual distances). Bottom row shows that snubfin dolphins occurred closer to river mouths than humpback dolphins. We considered the results significant (indicated in bold) if confidence intervals around effect sizes indicated plausible substantial differences and $\mathrm{p}$-values were low $(\mathrm{p}<0.1)$.

\begin{tabular}{|c|c|c|c|}
\hline & Distance to land (km) & Distance to river mouth $(\mathrm{km})$ & Water depth (m) \\
\hline $\begin{array}{l}\text { Snubfin } \\
\text { Humpback } \\
\text { Snubfin-humpback }\end{array}$ & $\begin{array}{l}-3.1(-4.4,-1.8), 0.001 \\
-\mathbf{2 . 3}(-\mathbf{5 . 2}, \mathbf{1 . 5}), \mathbf{0 . 0 6 7 *} \\
-0.8(-4.6,2.1), 0.622\end{array}$ & $\begin{aligned}-0.1 & (-2.3,1.4), 0.459 \\
& 4.7(1.1,7.3), 0.984 \\
\mathbf{- 4 . 8} & (-\mathbf{8 . 3}, \mathbf{- 1 . 4}), \mathbf{0 . 0 1 3}\end{aligned}$ & $\begin{aligned} & 1.0(-1.3,4.4), 0.778 \\
& 5.1(2.7,8.0), 0.984 \\
&-4.1(-7.7,0.1), 0.120\end{aligned}$ \\
\hline
\end{tabular}

*The effect size of distance to land on the distribution of humpback dolphins is not as evident as the one for snubfin dolphins (i.e. confidence intervals around effect size are wide).

(Table 1), but humpback dolphins also tend to occur in water close to the coast. There was a significant difference between the mean distances to river at which both species were sighted, with snubfin dolphins occurring closer to river mouths than humpback dolphins (Table 1).

\section{Mantel tests: correlation between dolphin distribution and environmental variables}

Dolphin occurrence was significantly correlated with environmental variables measured (Table 2, upper diagonal). The distribution of dolphins and the environmental variables were spatially autocorrelated (Table 2, upper diagonal); however, the correlation between dolphin occurrence and environmental variables remained significant after the spatial autocorrelation of the environmental data was accounted for (Table 2, lower diagonal). The spatial autocorrelation within the dolphin occurrence matrix disappeared once the effect of the environment was removed (Table 2, lower diagonal), indicating this was a result of correlation with the environmental variables we measured (or any other variable correlated with these variables) and not the result of spurious correlations with some unquantified variables (e.g. dolphins' social structure).

Once the environmental dissimilarity matrix was separated into individual matrices (i.e. separate predictor variables), both simple (Table 3, column 1) and partial Mantel tests controlling for spatial autocorrelation (column 3) and intercorrelation (column 4) between variables, indicated that the spatial distribution of dolphins was influenced by all 3 environmental variables.

\section{Mantel tests: correlation between dolphin species' composition and environmental variables}

We detected significant correlations between the dolphin species composition at each sampling site and the multivariate environment matrix, before and after controlling for the spatial structure in environmental data (Table 4). This correlation suggests that there was some measurable interspecific difference in the spatial distribution of snubfin and humpback dolphins in relation to the environmental variables investigated. Once the multivariate environmental dissimilarity matrix was separated into its constituent variables (Table 5), the results indicated that the only variable that had an effect on dolphin species' composition was distance to river mouth. This correlation indicates specific differences in the spatial distribution of the dolphins in relation to distance to river mouth, with snubfin dolphins occurring closer to river mouths than humpback dolphins (Fig. 2).

\section{Discussion}

\section{Spatial distribution}

Our results indicated that snubfin and humpback dolphins occurred mostly in waters $<15$ m deep that

Table 2. Simple (upper diagonal) and partial (lower diagonal) Mantel coefficients $\left(\mathrm{r}_{\mathrm{M}}\right)$ ( $95 \%$ confidence intervals in parenthesis) followed by corresponding p-values for the correlation between dolphin occurrence (i.e. presence/absence of dolphins of either species), environmental variables, and geographic distance (Space) in study area. We considered the results significant (indicated in bold) if confidence intervals around effect sizes indicated plausible substantial differences and $\mathrm{p}$-values were low $(\mathrm{p}<0.1)$.

\begin{tabular}{|c|c|c|c|}
\hline & $\begin{array}{l}\text { Dolphin occurrence } \\
\mathrm{r}_{\mathrm{M}}\end{array}$ & $\begin{array}{l}\text { Environmental variables } \\
\mathrm{r}_{\mathrm{M}}\end{array}$ & $\begin{array}{c}\text { Space } \\
\mathrm{r}_{\mathrm{M}}\end{array}$ \\
\hline Dolphin occurrence & $0114(0.0640172) 0006$ & $0.128(0.075,0.199), 0.003$ & $0.066(0.014,0.123), 0.023$ \\
\hline Space & $0.029(-0.012,0.087), 0.126$ & $0.296(0.258,0.334), 0.001$ & \\
\hline
\end{tabular}


Table 3. Simple and partial Mantel coefficients $\left(r_{M}\right)(95 \%$ confidence intervals in parenthesis) followed by corresponding p-values for the correlation between dolphin occurrence (i.e. presence/absence of dolphins of either species), individual environmental variables, and geographic distance (Space) in the study area. We considered the results significant (indicated in bold) if confidence intervals around Mantel coefficients indicated plausible substantial correlations and p-values were low $(\mathrm{p}<0.1)$.

\begin{tabular}{|c|c|c|c|c|}
\hline & $\begin{array}{c}\text { Dolphin occurrence }^{\mathrm{a}} \\
\mathrm{r}_{\mathrm{M}}\end{array}$ & $\begin{array}{c}\text { Space }^{\mathrm{b}} \\
\mathrm{r}_{\mathrm{M}}\end{array}$ & $\begin{array}{c}\text { Dolphin occurrence | } \\
\text { Space }^{c} \\
\mathrm{r}_{\mathrm{M}}\end{array}$ & $\begin{array}{c}\text { Dolphin occurrence } \mid \text { All }^{\mathrm{d}} \\
\mathrm{r}_{\mathrm{M}}\end{array}$ \\
\hline $\begin{array}{r}\text { Dolp } \\
\text { occ }\end{array}$ & & $0.066(0.014,0.123), 0.031$ & & $(-0.016,0.07$ \\
\hline $\begin{array}{l}\text { Distance to } \\
\text { land }\end{array}$ & $0.113(0.059,0.181), 0.021$ & $0.245(0.201,0.293), 0.004$ & $0.101(0.047,0.169), 0.025$ & $0.109(0.058,0.177), 0.023$ \\
\hline $\begin{array}{l}\text { Distance to } \\
\text { river } \\
\text { mouth }\end{array}$ & $0.066(0.023,0.128), 0.034$ & $0.191(0.149,0.245), 0.005$ & $0.054(0.011,0.110), 0.048$ & $0.050(0.009,0.108), 0.069$ \\
\hline Water depth & $0.074(0.024,0.138), 0.031$ & $0.015(-0.050,0.083), 0.381$ & $0.073(0.021,0.137), 0.031$ & $0.071(0.021,0.140), 0.041$ \\
\hline
\end{tabular}

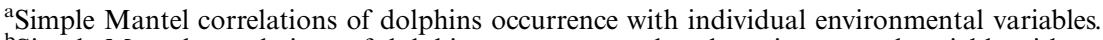

${ }^{\mathrm{b}}$ Simple Mantel correlations of dolphin occurrence and each environmental variable with space (autocorrelation).

${ }^{c}$ Partial Mantel correlation of dolphin occurrence with individual environmental variables controlling for space.

${ }^{\mathrm{d}}$ First row of fourth column indicates Partial Mantel correlation of dolphin occurrence with space controlling for all environmental variables. The rest of the column indicates partial Mantel correlations of dolphin occurrence with individual environmental variables controlling for all other variables.

were within $10 \mathrm{~km}$ of the coast and $20 \mathrm{~km}$ from the nearest river mouth. This result conforms with reviews of the distribution of both species along the Queensland coast (Corkeron et al. 1997, Parra et al. 2002, 2004) and throughout their range (Stacey and Arnold 1999, Jefferson and Karczmarski 2001).

The Mantel test results indicated spatial autocorrelation both in the distribution of dolphins and in environmental data, reiterating the importance of considering spatial autocorrelation in the analysis of species-environment relationships. Allowing for the spatial autocorrelation in environmental data, the dolphins were influenced by the environmental variables that we measured. Further, when comparing between species, it appears that interspecific differences in spatial distribution were related to proximity to river mouths; snubfin dolphins occurred closer to river mouths than humpback dolphins.

Cetacean distributions generally are determined by physical oceanographic and hydrographic features, and the effects of these features on prey distributions (Jaquet and Whitehead 1996, Davis et al. 1998, 2002, Jaquet and Gendron 2002, Benson et al. 2002). Nutrient input from rivers, the export of organic litter from mangrove forests, and the stratification and circulation patterns created in shallow coastal waters enhance productivity in tropical coastal areas, creating important nursery areas for fish (Robertson and Duke 1987, Hobbie 2000). Preference by snubfin and humpback dolphins for nearshore, estuarine areas may be related to their diet, but quantitative studies on their foraging ecology are limited. The available data suggest that both species are opportunistic-generalist feeders, eating a wide variety of coastal, estuarine, and nearshore reef-associated fishes (Heinsohn 1979, Barros et al. 2004).

Most delphinids are sociable animals and habitat selection by individuals may be influenced by the behaviour and distribution of conspecifics. Such attractions can result in spatial autocorrelation in their distribution that could not be explained by the environmental variables measured (Legendre and Fortin 1989, Legendre 1993, Lichstein et al. 2002). As this was not the case in this study, we can conclude that the environmental variables measured, and their potential effect on prey distribution and availability, had a major influence

Table 4. Simple and partial Mantel coefficients $\left(r_{M}\right)$, confidence intervals, and p-values for the correlation between dolphin species' composition (i.e. presence/absence of snubfin and/or humpback dolphins), environmental variables, and geographic distance (Space) in the study area. Elements in the upper triangle of the matrix are simple correlations, whereas those in the lower triangle are partial correlations. We considered the results significant (indicated in bold) if confidence intervals around Mantel coefficients indicated plausible substantial correlations and $\mathrm{p}$-values were low $(\mathrm{p}<0.1)$.

\begin{tabular}{|c|c|c|c|}
\hline & $\begin{array}{l}\text { Dolphin species composition } \\
\mathrm{r}_{\mathrm{M}}\end{array}$ & $\begin{array}{l}\text { Environmental variables } \\
\mathrm{r}_{\mathrm{M}}\end{array}$ & $\underset{\mathrm{r}_{\mathrm{M}}}{\text { Space }}$ \\
\hline $\begin{array}{l}\text { Dolphin species composition } \\
\text { Environmental variables } \\
\text { Space }\end{array}$ & $\begin{array}{r}\mathbf{0 . 2 3 0}(\mathbf{0 . 1 4 0 ,} \mathbf{0 . 3 4 0} \\
-0.088(-0.149\end{array}$ & $\begin{array}{l}0.215(0.134,0.320), 0.024 \\
0.283(0.189,0.386), 0.014\end{array}$ & $\begin{array}{c}-0.024(-0.084,0.025), 0.500 \\
\mathbf{0 . 2 7 1}(\mathbf{0 . 1 9 0 , 0 . 3 7 2 ) , 0 . 0 1 7}\end{array}$ \\
\hline
\end{tabular}


on the spatial distribution of snubfin and humpback dolphins in the study area.

From surveys of these preselected sites in the month of October (mainly in the morning hours), and our small sample size, we cannot make robust inferences about the generality of these findings. However, this study confirms and refines the more qualitative observations made on broader scale surveys on the distribution of these species in waters of the Great Barrier Reef Marine Park (Corkeron et al. 1997, Parra et al. 2002) and agrees with detailed studies on space, and habitat use from a selected area along the Queensland coast (Parra 2005). Preliminary surveys of snubfin dolphins off the Kimberley coast, northwest Australia, indicated animals were found in habitats similar to the ones reported here (Thiele 2005).

\section{Implications for conservation}

We have identified environmental features that delineate potential suitable and important areas for snubfin and humpback dolphins. Our aim with this study was to define distinct and workable boundaries for the management of the coastal area in relation to coastal dolphins, in order to facilitate their management and conservation.

Although most of Australia's coastline is relatively uninhabited and unindustrialized, increasing development and settlement of human populations in coastal locations, including the Queensland coast, has become an important issue affecting the sustainability of many of Australia's marine and coastal resources (Zann 1996). It has been estimated that at least half of the land area of catchments adjacent to the Great Barrier Reef has been modified for grazing, farming, and mining activities (Haynes and Michalek-Wagner 2000). This pattern of land use has stimulated concern about water quality and the potential impacts these activities might have on the ecological integrity of nearshore environments and their associated fauna along the Queensland Coast (Haynes and Johnson 2000, Haynes and Michalek-Wagner 2000, Haynes et al. 2000). Significant measures have been implemented to address this issue including monitoring programs and water quality targets (Anon. 2001).

The finding that snubfin dolphins occurred closer to river mouths than humpback dolphins may be particularly important. Drowning in nearshore gillnets set across creeks, rivers, and shallow estuaries represents one of the major threats to nearshore dolphins along the Queensland coast (Paterson 1990, Hale 1997). Snubfin dolphins appear to be the rarest of Queensland's coastal dolphins (Parra et al. 2002). The results of this study together with other studies along the Queensland coast suggest that their habitat preferences put them at greater 
risk of encountering river-set gillnets than other dolphins.

The results presented here also reveal concerns related to the recent (2004) rezoning of the Great Barrier Reef Marine Park (<http://www.gbrmpa.gov.au/corp_site/ management/zoning/rap/rap/index.html $>$ ) particularly within the study areas. The current zoning plan for the Far Northern Section delineates a large area of Princess Charlotte Bay into a Marine National Park Zone, where gillnetting is banned. However, the remainder of Princess Charlotte Bay (Fig. 1) is currently zoned as 3 different Special Management Areas. Commercial gillnetting (except for offshore set nets) is allowed in these Special Management Areas, subject to a Great Barrier Reef Marine Park Authority permit. However, Bathurst Bay and most of Ninian Bay (Fig. 1) are zoned as Conservation Park Zones where netting activities are prohibited.

The current boundaries of the Marine National Park Zone in Princess Charlotte Bay provide limited protection to snubfin, humpback dolphins, and other coastal species (e.g. dugongs Dugong dugon) as the MNPZ is situated mainly in offshore waters. Waters around the western side of Bathurst Head, zoned as a Special Management Area, appear to be a hotspot for aggregations of snubfin and humpback dolphins (Fig. 1). Fortunately under the provisions of these Special Management Areas, the number of gillnets licensed to work in this region has been limited to $<10$. In addition, the fishery is closed for 3 months of the year (1 November-1 February) and other restrictions on netting practice are being implemented.

The entire Far Northern Section of the Great Barrier Reef Marine Park is very remote, relatively unpopulated, and difficult to police (Gribble and Robertson 1998). The efficacy of acoustic alarms to reduce incidental captures in gillnets (Barlow and Cameron 2003) remains undemonstrated for humpback and snubfin dolphins, and enforcing regulations regarding their use in this remote region is impractical. Whether current management measures will be adequate to protect dolphin populations is unknown. If management goals of protected areas in this region include protecting nearshore dolphins, the areas banning netting should be increased to cover these important coastal areas.

Acknowledgements - We thank Queensland Parks and Wildlife for providing assistance and access to their boat to carry out the surveys. Special thanks go to M. Short, C. Briggs, S. Selwood, A. Fergusson, and A. Hurlbatt for their help, endurance, and patience during long hours at sea. Thanks are given to S. Dufresne and S. Dawson for providing information on line transect methodology and sharing their observer training manual. H. Marsh and P. Arnold provided helpful suggestions and valuable input into this manuscript. We are also very thankful to S. Goslee and D. Urban for providing access to the R-library package to carry out the Mantel tests, and to G. Hood (for POPTOOLS) and R Core Development Team for providing such powerful and free tools. Thanks to A. Lewis for providing access to the GBR depth model, and Craig Smith for access to the Queensland estuaries database. This work was funded by the
National Heritage Trust "Coast and Clean Seas" programme and the CRC Reef Research Centre. G. J. Parra gratefully acknowledges the stipend and fees provided by an International Postgraduate Research Award from James Cook Univ. Fieldwork was carried out under a permit from the Great Barrier Reef Marine Park Authority and with ethical approval from James Cook Univ.

\section{References}

Anderson, D. R. et al. 2001. Suggestions for presenting the results of data analyses. - J. Wildl. Manage. 65: 373-378.

Anon. 1996. ArcView spatial analyst: advanced spatial analysis using raster and vector data. - Environmental Systems Research Inst.

Anon. 2000. Whale and dolphin conservation in the Great Barrier Reef Marine Park: policy document. - The Great Barrier Reef Marine Park Authority, Townsville, Queensland, Australia.

Anon. 2001. The Great Barrier Reef Water Quality Action Plan. - The Great Barrier Reef Marine Park Authority, Townsville, Queensland, Australia.

Bannister, J. L., Kemper, C. M. and Warneke, R. M. 1996. The Action Plan for Australian Cetaceans. - Australian Nature Conservation Agency, Canberra.

Barlow, J. and Cameron, G. A. 2003. Field experiments show that acoustic pingers reduce marine mammal bycatch in the California drift gill net fishery. - Mar. Mammal Sci. 19: 265-283.

Barlow, J., Gerrodette, T. and Silber, G. 1997. First estimates of vaquita abundance. - Mar. Mammal Sci. 13: 44-58.

Barros, N. B., Jefferson, T. A. and Parsons, E. C. M. 2004. Feeding habits of Indo-Pacific humpback dolphins (Sousa chinensis) stranded in Hong Kong. - Aquat. Mammal 30: $179-188$.

Beasley, I., Robertson, K. M. and Arnold, P. 2005. Description of a new dolphin, the Australian snubfin dolphin Orcaella heinsohni sp. n. (Cetacea, Delphinidae). - Mar. Mammal Sci. 21: 365-400.

Benjamini, Y. and Hochberg, Y. 1995. Controlling the false discovery rate: a practical and powerful approach to multiple testing. - J. R. Stat. Soc. B 57: 289-300.

Benson, S. R. et al. 2002. Changes in the cetacean assemblage of a coastal upwelling ecosystem during El Niño 1997-98 and La Niña 1999. - Progr. Oceanogr. 54: 279-291.

Borcard, D., Legendre, P. and Drapeau, P. 1992. Partialling out the spatial component of ecological variation. - Ecology 73 : $1045-1055$.

Bräger, S. et al. 2002. Site fidelity and along-shore range in Hector's dolphin, an endangered marine dolphin from New Zealand. - Biol. Conserv. 108: 281-287.

Bräger, S., Harraway, J. A. and Manly, B. F. J. 2003. Habitat selection in a coastal dolphin species (Cephalorhynchus hectori ). - Mar. Biol. 143: 233-244.

Buckland, S. T. et al. 1993. Distance sampling: estimating abundance of biological populations. - Chapman and Hall.

Caswell, W. et al. 1998. Harbor porpoise and fisheries: an uncertainty analysis of incidental mortality. - Ecol. Appl. 8: $1226-1238$.

Chilvers, B. L. and Corkeron, P. J. 2001. Trawling and bottlenose dolphins' social structure. - Proc. R. Soc. B 268: 1901-1905.

Colegrave, N. and Ruxton, G. D. 2003. Confidence intervals are a more useful complement to nonsignificant tests than are power calculations. - Behav. Ecol. 14: 446-447.

Connor, R. C. et al. 1998. Social evolution in toothed whales. - Trends Ecol. Evol. 13: 228-232.

Corkeron, P. J. et al. 1997. Distribution and status of humpbacked dolphins, Sousa chinensis, in Australian waters. - Asian Mar. Biol. 14: 49-59. 
Davis, R. W. et al. 1998. Physical habitat of cetaceans along the continental slope in the north-central and western Gulf of Mexico. -Mar. Mammal Sci. 14: 490-507.

Davis, R. W. et al. 2002. Cetacean habitat in the northern oceanic Gulf of Mexico. - Deep-Sea Res. Part I - Oceanogr. Res. Pap. 49: 121-142.

Efron, B. and Tibshirani, R. J. 1993. An introduction to the bootstrap. - Chapman and Hall.

Gribble, N. A. and Robertson, J. W. A. 1998. Fishing effort in the far northern section cross shelf closure area of the Great Barrier Reef Marine Park: the effectiveness of area-closures. - J. Environ. Manage. 52: 53-67.

Hale, P. 1997. Conservation of inshore dolphins in Australia. - Asian Mar. Biol. 14: 83-91.

Haynes, D. and Johnson, J. E. 2000. Organochlorine, heavy metal and polyaromatic hydrocarbon pollutant concentrations in the Great Barrier Reef (Australia) environment: a review. - Mar. Pollut. Bull. 41: 267-278.

Haynes, D. and Michalek-Wagner, K. 2000. Water quality in the Great Barrier Reef World Heritage Area: past perspectives, current issues and new research directions. - Mar. Pollut. Bull. 41: 428-434.

Haynes, D., Muller, J. and Carter, S. 2000. Pesticide and herbicide residues in sediments and seagrasses from the Great Barrier Reef World Heritage area and Queensland coast. - Mar. Pollut. Bull. 41: 279-287.

Heinsohn, G. E. 1979. Biology of small cetaceans in north Queensland Waters. - The Great Barrier Reef Marine Park Authority, Townsville, Queensland.

Hiby, A. R. and Hammond, P. S. 1989. Survey techniques for estimating the abundance of cetaceans. - Reports of the International Whaling Commission 11: 47-80.

Hobbie, J. E. 2000. Estuarine science: the key to progress in coastal ecological research. - In: Hobbie, J. E. (ed.), Estuarine science: a synthetic approach to research and practice. Island Press, pp. 1-11.

Hood, G. 2003. PopTools, version 2.5. - Available at <http:// www.cse.csiro.au/poptools >

Hooker, S. K., Whitehead, H. and Gowans, S. 1999. Marine protected area design and the spatial and temporal distribution of cetaceans in a submarine canyon. - Conserv. Biol. 13: $592-602$.

Hortal, J., Garcia-Pereira, P. and Garcia-Barros, E. 2004. Butterfly species richness in mainland Portugal: predictive models of geographic distribution patterns. - Ecography 27 : $68-82$.

Hulbert, I. A. R. and French, J. 2001. The accuracy of GPS for wildlife telemetry and habitat mapping. - J. Appl. Ecol. 38: $869-878$.

Ihaka, R. and Gentleman, R. 1996. R: a language for data analysis and graphics. - J. Comput. Graph. Stat. 5: 299314.

Jackson, J. B. C. et al. 2001. Historical overfishing and the recent collapse of coastal ecosystems. - Science 293: 629638.

Jaquet, N. and Whitehead, H. 1996. Scale-dependent correlation of sperm whale distribution with environmental features and productivity in the South Pacific. - Mar. Ecol. Progr. Ser. 135: 1-9.

Jaquet, N. and Gendron, D. 2002. Distribution and relative abundance of sperm whales in relation to key environmental features, squid landings and the distribution of other cetacean species in the Gulf of California, Mexico. - Mar. Biol. 141: 591-601.

Jefferson, T. A. 2000. Population biology of the Indo-Pacific hump-backed dolphin in Hong Kong waters. - Wildl. Monogr. 144: 1-65.

Jefferson, T. A. and Karczmarski, L. 2001. Sousa chinensis. - Mammal Species 655: 1-9.

Karczmarski, L. et al. 1999. Population analyses of Indo-Pacific humpback dolphins Sousa chinensis in Algoa Bay, Eastern Cape, South Africa. - Mar. Mammal Sci. 15: 1115-1123.
Karczmarski, L., Cockcroft, V. G. and McLachlan, A. 2000. Habitat use and preferences of Indo-Pacific humpback dolphins Sousa chinensis in Algoa Bay, South Africa. - Mar. Mammal Sci. 16: 65-79.

Keith, M. et al. 2002. Population characteristics of Indo-Pacific humpback dolphins at Richards Bay, South Africa: implications for incidental capture in shark nets. - S. Afr. J. Wildl. Res. 32: 153-162.

Keitt, T. H. et al. 2002. Accounting for spatial pattern when modeling organism-environment interactions. - Ecography 25: $616-625$.

Leduc, A. et al. 1992. Study of spatial components of forest cover using partial Mantel tests and path analysis. - J. Veg. Sci. 3: 69-78.

Legendre, P. 1993. Spatial autocorrelation-trouble or new paradigm. - Ecology 74: 1659-1673.

Legendre, P. and Fortin, M. J. 1989. Spatial pattern and ecological analysis. - Vegetatio 80: 107-138.

Legendre, P. and Legendre, L. 1998. Numerical ecology. - Elsevier.

Lerczak, J. A. and Hobbs, R. C. 1998. Calculating sighting distances from angular readings during shipboard, aerial, and shore-based marine mammal surveys. - Mar. Mammal Sci. 14: $590-598$

Lewis, A. 2001. Great Barrier Reef depth and elevation model: GBRDEM. - CRC Reef Research Centre, Townsville.

Lichstein, J. W. et al. 2002. Spatial autocorrelation and autoregressive models in ecology. - Ecol. Monogr. 72: 445-463.

Manly, B. F. J. 1997. Randomization, bootstrap and Monte Carlo methods in biology. - Chapman and Hall.

Mantel, N. 1967. The detection of disease clustering and a generalized regression approach. - Cancer Res. 27: 209220

Marsh, H. 2000. Evaluating management initiatives aimed at reducing the mortality of dugongs in gill and mesh nets in the Great Barrier Reef World Heritage Area. - Mar. Mammal Sci. 16: 684-694.

May, R. M. 1984. An overview: real and apparent patterns in community structure. - In: Strong, D. R. et al. (eds), Ecological communities: conceptual issues and the evidence. Princeton Univ. Press, pp. 3-16.

Ormerod, S. J. 2003. Current issues with fish and fisheries: editor's overview and introduction. - J. Appl. Ecol. 40: 204213.

Parra, G. J. 2005. Behavioural ecology of Irrawaddy, Orcaella brevirostris (Owen in Gray, 1866), and Indo-Pacific humpback dolphins, Sousa chinensis (Osbeck, 1765), in northeast Queensland, Australia: a comparative study. - Ph.D. thesis, School of Tropical Environment Studies and Geography, James Cook Univ., Townsville.

Parra, G. J. et al 2002. Distribution of Irrawaddy dolphins, Orcaella brevirostris, in Australian waters. - Raffles Bull. Zool. Suppl. 10: 141-154.

Parra, G. J., Corkeron, P. J. and Marsh, H. 2004. The IndoPacific humpback dolphin Sousa chinensis (Osbeck, 1765), in Australian waters: a summary of current knowledge. - Aquat. Mammal. 30: 197-206.

Paterson, R. A. 1990. Effects of long-term anti-shark measures on target and non-target species in Queensland Australia. - Biol. Conserv. 52: 147-159.

Pauly, D. et al. 2002. Towards sustainability in world fisheries. - Nature 418: 689-695.

Pichler, F. B. and Baker, C. S. 2000. Loss of genetic diversity in the endemic Hector's dolphin due to fisheries-related mortality. - Proc. R. Soc. B 267: 97-102.

Pressey, R. L. and Cowling, R. M. 2001. Reserve selection algorithms and the real world. - Conserv. Biol. 15: 275277.

Robertson, A. I. and Duke, N. C. 1987. Mangroves as nursery sites: comparisons of the abundance and species composition of fish and crustaceans in mangroves and other 
nearshore habitats in tropical Australia. - Mar. Biol. 96: 193-205.

Schick, R. S. and Urban, D. L. 2000. Spatial components of bowhead whale (Balaena mysticetus) distribution in the Alaskan Beaufort Sea. - Can. J. Fish. Aquat. Sci. 57: 2193-2200.

Stacey, P. J. and Arnold, P. W. 1999. Orcaella brevirostris. - Mammal Species 616: 1-8.

Thiele, D. 2005. Report of an opportunistic survey for Irrawaddy dolphins, Orcaella brevirostris, off the Kimberley coast, northwest Australia. - Working paper presented at the 57th International Whaling Commission annual meeting, Small Cetaceans Scientific Committee (IWC/SC57/ SM2), Ulsan, Republic of Korea.
Thomas, L. 1997. Retrospective power analysis. - Conserv. Biol. 11: 276-280.

Urban, D. et al. 2002. Extending community ecology to landscapes. - Ecoscience 9: 200-212.

Van Parijs, S. M., Smith, J. and Corkeron, P. J. 2002. Using calls to estimate the abundance of inshore dolphins: a case study with Pacific humpback dolphins Sousa chinensis. - J. Appl. Ecol. 39: 853-864.

Yoccoz, N. G. 1991. Use, oversuse, and misuse of significance test in evolutionary biology and ecology. - Bull. Ecol. Soc. Am. 72: 106-111.

Zann, L. P. 1996. The State of the Marine Environment Report for Australia (SOMER): process, findings and perspectives. - Ocean Coast. Manage. 33: 63-86.

Subject Editor: Douglas Kelt. 